\title{
The Optimum Way to a CPA
}

\author{
Ruixue Du \\ University of Wisconsin Stevens Point \\ Christine Schalow \\ University of Wisconsin Stevens Point
}

\begin{abstract}
The accounting profession has established the 150 semester hours of education requirement for Certified Public Accountants (CPAs) in all jurisdictions of the United States (except the US Virgin Islands. However, the requirement does not specify how the extra education should be earned. The purpose of this study is to recommend a course of action in the accounting curriculum to address the extra 30 semester hours above the typical 120 semester hours baccalaureate degree to meet the education requirements for the CPA, based on the quality of new accounting professionals as perceived by hiring CPAs. A survey using a Likert-type scale was administered to measure hiring CPAs perceptions of new accounting professionals' quality. The findings suggest the desire for new hires to have more study in general business and financial accounting, both at the undergraduate and graduate levels. This research provides insight into how the accounting student can best prepare themselves for a successful career in accounting and how the profession can draw effective new entrants.
\end{abstract}

\section{INTRODUCTION}

The accounting profession established the 150 semester hours of education requirement for Certified Public Accountants (CPAs) in all jurisdictions of the United States, except the US Virgin Islands; however, the requirement does not specify how the extra education should be earned. The AICPA has left discretion to academic institutions for how to attain 150 hours. This paper investigates which alternative produces the most qualified graduates. The purpose of this study is to recommend a course of action in the accounting curriculum to address the extra 30 semester hours above the typical 120 semester hours baccalaureate degree to meet the education requirements for the CPA. The basis for the recommendation to accounting curriculums is the quality of new accounting professionals as perceived by hiring CPAs. Most previous research has investigated new accounting professionals' quality by using pass rates on the CPA exam as a proxy for quality. This research investigates another proxy for the quality measurement, the hiring CPAs perception of qualifications. A survey using a Likert-type scale was administered to measure hiring CPAs perceptions of new accounting professionals' quality. 


\section{BACKGROUND}

Academic research on the effects of the 150-hour requirement has increased. Most research has focused on the supply of entry-level accountants, alternatives to acquire the 150 hours, audit quality and pass rates of recent CPA candidates. Conclusions in previous research have had policy implications, with Connecticut, Massachusetts and Wisconsin reversing their policy to require 150 hours to sit for the CPA exam, now allowing students to sit for the exam after 120 hours and require 150 hours for licensure. The ongoing debate about the 150-hour requirement has focused on theoretical implications but has been supported with limited empirical evidence. This research aims to fill the gap in the literature with empirical evidence.

Previous research into the effect of the 150-hour legislation has investigated the supply and quality of accountants (Allen \& Woodland, 2012; Boone \& Coe, 2002; Schroeder \& Franz, 2004). Evidence about increased quality as measured by higher CPA exam pass rates is mixed. Cumming and Ranklin and Read et al. found evidence of increases in CPA exam pass rates (Cumming John \& Rankin, 1999; Read, Raghunandan, \& Brown, 2001). However, Grant et al. indicated that CPA exam pass rate increases may be explained by other factors (Grant, Ciccotello, \& Dickie, 2002). Haen and Vandenberg investigated whether the differences in how the additional 30 credits beyond a bachelor's degree were obtained would have a difference on overall exam passing rates (Haen \& Vandenberg, 2013). Their results did not find a significant predictor between courses taken and overall exam pass rates. Menk et al. researched whether candidates having completed a graduate degree makes a difference in performance on the CPA exam over those who have only undergraduate degrees (Menk, Nagle, \& Rau, 2017). Their results indicated graduate degree holders perform better on the exam than undergraduate degree holders.

New accounting professionals' quality has been measured by using pass rates on the CPA exam as a proxy for quality in previous research. Given that the AICPA's 150-hour education requirement is designed to improve the quality of new CPA's, there may be a better proxy to capture the quality of these new accountants. This research surveyed CPAs in industry and public accounting to identify their perceptions of the skills of new CPAs. We then identify perceptions of which strategy is the optimum way to obtain the 30 additional hours. To identify the best allocation of the 30 additional hours, it is important to discover what has been achieved among new CPAs and what needs to be improved. This research provides insight into how accounting students can best prepare themselves for a successful career in accounting and how the profession can draw effective new entrants.

\section{RESEARCH QUESTIONS}

The primary objective for the 150-hour education requirement, in 1988 AICPA discussions, was to improve the qualifications of new accounting graduates by providing a broader, more liberal education. Practitioners (AICPA, AAA, and CPA firms) were calling for a greater emphasis on communication and interpersonal skills, teamwork, analytical thinking and a broad knowledge base. However, surveys have shown that most schools have offered either a Master in Accountancy, MBA or extra courses in the business curriculum (Shafer \& Kunkel 2001, Albrecht \& Salk 2000). The lack of an integrated 5-year program means that accounting students are not required to complete a broader, more liberal undergraduate accounting education. The result of the 150-hour requirement has been to impose additional costs with undefined benefits.

There is a need for accounting research to determine if the primary objective for the 150-hour education requirement, improvement in the quality of new accounting graduates, is being met. Most previous research has investigated new accounting professionals' quality by using pass rates on the CPA exam as a proxy for quality. This research investigates another proxy for the quality measurement, the hiring CPAs perception of qualifications.

Research Question 1: Whether CPA qualifications have improved (and which qualifications) since the implementation of the 150-hour requirement?

Journal of Accounting and Finance Vol. 19(4) 2019153 
Research Question 2: What is the best way to allocate the additional 30 hours?

To answer these questions, it is important to find out which qualifications have been achieved and which are yet to be achieved. Our survey asks respondents their perceptions of the qualifications of new CPAs, their strengths and weaknesses. Next, given these areas of concern, what do they perceive as the best way to attain the additional 30 hours of education.

This research provides information about the perceived qualifications of new CPAs. It identifies areas of strengths and areas that need improvement. The areas that need improvement can be studied to identify paths (or areas of study) for accounting students to consider when deciding how to fulfill the additional 30 credits, provide guidance for universities when determining accounting curriculum, provide insight to professional organizations (such as the AICPA and State Societies) and National and State Boards of Accountancy (such as NASBA) when determining accounting education requirements, and assist accounting faculty when advising our students in "how to become a CPA".

\section{METHODS}

\section{Sample}

The population of interest in this study is CPAs in the public sector as well as CPAs in industry in the United States. In order to reach our population, a survey was distributed through an online survey platform to a national CPAs mail list. The respondents are the sample of this study.

\section{Survey}

To answer the two proposed research questions, a survey was designed to identify what has been achieved among new CPAs and what needs to be improved. A copy of the survey is included in Appendix. A total of 350 responses from CPAs in industry and CPAs in the public were received. Among these responses, 120 surveys were unfinished, which left us with 230 valid responses.

As presented in Table 1, 216 (96\%) respondents are CPAs in the public sector. Fourteen of them (4\%) are CPAs in industry. These two groups of respondents are the major concern of this study.

\section{TABLE 1}

\section{RESPONDENTS STATUS}

\begin{tabular}{ccc} 
Status & $\mathrm{N}$ & Percent \\
\hline CPAs in public & 216 & 0.94 \\
CPAs in industry & 14 & 0.06 \\
\hline
\end{tabular}

About $13 \%$ of the respondents are classified as Other, which are part of the CPAs mail list but do not currently work in the public sector, nor in industry as CPAs.

\section{Variables}

Quality

Fifteen quality measure questions have been included in the survey to ask the respondents their opinions on whether the qualities of new CPAs, since the implementation of the 150-hour rule, have changed. These quality measures were developed by De Berry based on the published discussions of the 150-hour requirement (De Berry, 2003).

\section{Areas Improved}

Respondents are asked to evaluate, among the four CPA exam sections, in which area(s) they have seen improvements from new CPAs, since the implementation of the 150-hour requirement. The four areas are: auditing, financial, general business, and regulation. 


\section{How to Obtain the Additional 30-credit-hour}

In order to fulfill the 150-hour requirement, students have several different options to obtain the additional 30-credit-hour. Based on their perceptions of what has been achieved among new CPAs and what needs to be improved, the respondents are asked to choose what is the optimum way to fulfill the 150-hour requirement. Four strategies are identified as alternatives: a master's degree in accounting, one additional year in college, pick up a second major or minor, and taking online credits while working.

\section{RESULTS}

\section{Research Questions 1}

Whether New CPAs Have Improved in Their Qualities Since the Implementation of the 150-hour Requirement?

CPAs working in industry, as well as working in the public sector, were surveyed on their views regarding new CPAs' qualities since the implementation of the 150-hour requirement. The respondents were asked to rate the new CPAs on 15 quality measures based on a -3 to 3 scale, with -3 means new CPAs' quality is dramatically worse since the implementation of 150-hour requirement, and 3 means dramatically better. The responses are summarized in Table 2.

TABLE 2

\section{NEW CPAS QUALITIES SINCE THE IMPLEMENTATION OF THE 150-HOUR REQUIREMENT}

\begin{tabular}{lcr} 
Quality & $\mathrm{N}$ & Mean \\
\hline 1. Analytical abilities & 230 & 0.34 \\
2. Problem-solving skills & 230 & 0.27 \\
3. Professionally ethical behavior & 230 & 0.17 \\
4. Communication skills & 230 & 0.17 \\
5. Appreciation/knowledge of the arts, current events, etc. & 230 & 0.16 \\
6. Competency with complex accounting & 230 & 0.16 \\
7. Understanding of other business fields & 230 & 0.19 \\
8. Commitment to the employer & 230 & -0.42 \\
9. Commitment to the profession & 230 & -0.05 \\
10. People skills & 230 & 0.04 \\
11. Positive responsiveness to change & 230 & 0.29 \\
12. Maturity and professional judgment & 230 & 0.26 \\
13. Productivity & 230 & -0.07 \\
14. Amount of internal training needed & 230 & -0.04 \\
15. Amount of supervision needed & 230 & -0.07 \\
\hline
\end{tabular}

Respondents from both sectors agree that new CPAs have improved in their analytical abilities, problem-solving skills, communication skills, appreciation/knowledge of the arts and current events, competency with complex accounting, understanding of other business fields, people skills, positive responsiveness to change, and maturity and professional judgment. New CPAs need less supervision and 
internal training. However, decreases in productivity, commitment to employers and the profession from new CPAs have been reported.

\section{Research Questions 2}

What Is the Best Way to Allocate the Additional 30 Hours?

The accounting profession has established the 150 semester hours of education requirement for Certified Public Accountants (CPAs) in all jurisdictions of the United States (except the US Virgin Islands). However, there is still an ongoing discussion regarding how to best allocate the 30 additional hours. In order to answer this question, it is important to find out what have been achieved and what are still yet to be achieved among new CPAs.

2a. In Which of the Four Sreas, General Business, Financial Accounting, Auditing, and Regulation, New CPAs Have Improved Since the Implementation of the 150-hour Requirement?

Twenty-nine percent of CPA respondents do not consider there is any improvement among new CPAs in any of the four areas. Improvements have been observed in General Business and Financial Accounting among new CPAs by about 27 percent of the respondents. Improvement in the auditing area has been reported by eight percent of the respondents. The results to this question are summarized in Table 3.

TABLE 3

AREAS NEW CPAS HAVE IMPROVED SINCE THE IMPLEMENTATION OF THE 150-HOUR REQUIREMENT

\begin{tabular}{lcc} 
Areas Improved & N & Percent \\
\hline NA & 6 & 0.29 \\
Auditing & 9 & 0.08 \\
Financial Accounting & 3 & 0.27 \\
General Business & 2 & 0.27 \\
Regulation & 0 & 0.09 \\
\hline
\end{tabular}

2b. How Should the Additional 30-credit Hours be Allocated to General Business, Financial Accounting, Auditing, and Regulation?

Respondents were asked to allocate 30-credit hours among the four CPA exam areas, General Business, Financial Accounting, Auditing, and Regulation. Financial Accounting receives the highest mean points allocation (9.83), followed by General Business (9.72). These results are provided in Table 4. 
TABLE 4

HOW TO ASSIGN THE ADDITIONAL 30-CREDIT HOURS

\begin{tabular}{lccccccc} 
Areas & $\mathrm{N}$ & Min & $\mathrm{Q} 1$ & Median & $\mathrm{Q} 3$ & Max & Mean \\
\hline Auditing & 230 & 0 & 0 & 5 & 9.75 & 20 & 5.37 \\
Financial Accounting & 230 & 0 & 5 & 10 & 12.00 & 30 & 9.83 \\
General Business & 230 & 0 & 5 & 10 & 15.00 & 30 & 9.72 \\
Regulation & 230 & 0 & 0 & 5 & 9.00 & 18 & 5.10 \\
\hline
\end{tabular}

2c. Which Would Be Best Strategy to Obtain the 30 Additional Credit Hours?

As shown in Table 5, about 47 percent of the respondents believe that a master's degree in accounting is the best strategy to obtain the 30 additional credit hours.

TABLE 5

HOW TO OBTAIN THE ADDITIONAL 30-CREDIT HOURS

\begin{tabular}{lcc}
\multicolumn{1}{c}{ Strategy } & N & Percent \\
\hline NA & 1 & 0.00 \\
A master's degree in accounting & 109 & 0.47 \\
One additional year in college & 36 & 0.16 \\
Pick up a second major or minor & 26 & 0.11 \\
Taking online credits while working & 58 & 0.25 \\
\hline
\end{tabular}

\section{DISCUSSION}

The purpose of this study is to recommend a course of action in the accounting curriculum to address the extra 30 semester hours above the typical 120 semester hours baccalaureate degree to meet the education requirements for the CPA. The basis for the recommendation to accounting curriculums is the quality of new accounting professionals as perceived by hiring CPAs. This study surveyed CPAs in industry and public accounting to identify their perceptions of the skills of new CPAs and their opinions on the optimum way to obtain the 150 hours. CPAs in industry and public accounting agree that they have seen improvements in many of the new CPAs quality measures, although not in a large scale. They also agree that new CPAs need less supervision. New CPAs are also considered less committed to both employers and the profession by the respondents. However, it is difficult to determine if these characteristics are a result of the 150 hours or another variable.

General business and financial accounting are the two areas that new CPAs have shown the most improvement. These results are consistent with the hiring CPAs' pick on the best strategy, a master's degree in accounting, to obtain the 150 hours. 


\section{CONCLUSIONS AND RECOMMENDATIONS}

Combining these findings with the responses on how to obtain the additional 30-credit hours, a master's degree in accounting with some special focus on general business and financial accounting seems most likely to be the best strategy considered by the current CPAs. Besides the required general business and financial accounting courses, accounting students might benefit from additional elective courses in those areas, as well. This curriculum recommendation does not only apply to the master's program, undergraduate students might also benefit from additional elective courses in general business and financial accounting. These results support the AICPAs' original call for more education for accounting students to "improve the overall quality of work performed by CPAs confronted with advancing technology, an increasingly complex business environment, and society's continuing demand for accounting and assurance services." Due to the technical nature of the accounting profession, new CPAs could benefit from more study in the areas of general business and financial accounting to meet the growing demands of the profession. Current CPAs do recommend a master's degree in accounting over all other options as the optimum way to a CPA. Future research is needed to track the effectiveness of accounting education as the profession responds to future needs.

\section{LIMITATIONS}

There are several limitations to this study. First, the sample size is somewhat small, considering the population of interest. Second, there might be self-selection bias in the responses. When a large amount of invitations to a survey were sent out, recipients with strong feelings about CPA quality issues tend to respond to survey more than other recipients.

\section{REFERENCES}

Allen, A. C., \& Woodland, A. M. (2012). Response to: The ongoing debate about the impact of the 150hour education requirement on the supply of Certified Public Accountants. Issues in Accounting Education, 27(4), 1045-1057.

Boone, J. P., \& Coe, T. L. (2002). The 150-hour requirement and changes in the supply of accounting undergraduates: Evidence from a quasi-experiment. Issues in Accounting Education, 17(3), 253268.

Cumming, J., \& Rankin, L. J. (1999). 150 hours: A look back.

De Berry, T. W. (2003). The 150-hour requirement and CPA quality. The CPA Journal, August(73), 2630.

Grant, C. T., Ciccotello, C. S., \& Dickie, M. (2002). Barriers to professional entry: How effective is the 150-hour rule? Journal of Accounting and Public Policy, 21(1), 71-93.

Haen, J., \& Vandenberg, A. (2013). Does the Path to Completion of 150 Credit Hours Affect CPA Exam Pass Rates? The Accounting Educators' Journal, 23, 113-126.

Menk, K. B., Nagle, B. M., \& Rau, S. E. (2017). Does Earning a Graduate Degree Impact CPA Exam Performance? Academy of Business Research Journal, 1, 27-42.

Read, W. J., Raghunandan, K., \& Brown, C. D. (2001). 150-Preparation improves CPA exam performance. The CPA Journal, 71(March), 30-33.

Schroeder, N. W., \& Franz, D. R. (2004). Explaining the Decline in. The CPA Journal, 74(10), $62-66$. 


\section{APPENDIX}

\section{Survey}

Q1 How would you describe your current status?
$O$ A. An undergraduate student majoring in accounting
$\mathrm{O}$ B. A master's student majoring in accounting
C C. A CPA in an public accounting firm
$\mathrm{O}$ D. A CPA in industry
E $\quad$ A CPA in the government sector
F. A CPA in education
O G. Other

Q2 Since the implementation of the 150-hour requirement, how much improvement in the following qualities have you seen from new hire staff accountants? 3 means dramatically improved and -3 means dramatically worse.

\begin{tabular}{|c|c|c|c|c|c|c|c|}
\hline & -3 & -2 & -1 & 0 & 1 & 2 & 3 \\
\hline 1. Analytical abilities & $\mathrm{O}$ & $\mathrm{O}$ & $\mathrm{O}$ & $\mathrm{O}$ & $\mathrm{O}$ & $\mathrm{O}$ & $\mathrm{O}$ \\
\hline 2. Problem-solving skills & $\mathrm{O}$ & O & O & $\mathrm{O}$ & $\mathrm{O}$ & $\mathrm{O}$ & $\mathrm{O}$ \\
\hline $\begin{array}{l}\text { 3. Professionally ethical } \\
\text { behavior }\end{array}$ & $\mathrm{O}$ & $\mathrm{O}$ & $\mathrm{O}$ & $\mathrm{O}$ & $\mathrm{O}$ & $\mathrm{O}$ & $\mathrm{O}$ \\
\hline 4. Communication skills & $\mathrm{O}$ & $\mathrm{O}$ & O & $\mathrm{O}$ & $\mathrm{O}$ & $\mathrm{O}$ & $\mathrm{O}$ \\
\hline $\begin{array}{l}5 . \\
\text { Appreciation/knowledge } \\
\text { of the arts, current events, } \\
\text { etc. }\end{array}$ & $\mathrm{O}$ & $\mathrm{O}$ & O & O & $\mathrm{O}$ & $\mathrm{O}$ & $\mathrm{O}$ \\
\hline $\begin{array}{l}\text { 6. Competency with } \\
\text { complex accounting }\end{array}$ & $\mathrm{O}$ & O & 0 & $\mathrm{O}$ & O & O & O \\
\hline $\begin{array}{l}\text { 7. Understanding of other } \\
\text { business fields }\end{array}$ & $\mathrm{O}$ & $\mathrm{O}$ & O & $\mathrm{O}$ & $\mathrm{O}$ & O & $\mathrm{O}$ \\
\hline $\begin{array}{l}\text { 8. Commitment to the } \\
\text { employer }\end{array}$ & O & O & O & O & $\mathrm{O}$ & $\mathrm{O}$ & $\mathrm{O}$ \\
\hline $\begin{array}{l}\text { 9. Commitment to the } \\
\text { profession }\end{array}$ & $\mathrm{O}$ & O & O & O & O & O & O \\
\hline 10. People skills & $\mathrm{O}$ & $\mathrm{O}$ & $\mathrm{O}$ & $\mathrm{O}$ & $\mathrm{O}$ & $\mathrm{O}$ & $\mathrm{O}$ \\
\hline $\begin{array}{l}\text { 11. Positive } \\
\text { responsiveness to change }\end{array}$ & O & $\mathrm{O}$ & $\mathrm{O}$ & O & $\mathrm{O}$ & $\mathrm{O}$ & $\mathrm{O}$ \\
\hline $\begin{array}{l}\text { 12. Maturity and } \\
\text { professional judgment }\end{array}$ & O & $\mathrm{O}$ & O & O & $\mathrm{O}$ & $\mathrm{O}$ & $\mathrm{O}$ \\
\hline 13. Productivity & O & O & $\mathrm{O}$ & $\mathrm{O}$ & O & $\mathrm{O}$ & $\mathrm{O}$ \\
\hline $\begin{array}{l}\text { 14. Amount of internal } \\
\text { training needed }\end{array}$ & $\mathrm{O}$ & $\mathrm{O}$ & O & $\mathrm{O}$ & $\mathrm{O}$ & $\mathrm{O}$ & $\mathrm{O}$ \\
\hline $\begin{array}{l}\text { 15. Amount of supervision } \\
\text { needed }\end{array}$ & 0 & $\mathrm{O}$ & $\mathrm{O}$ & $\mathrm{O}$ & $\mathrm{O}$ & $\mathrm{O}$ & 0 \\
\hline
\end{tabular}


Q3 In which of the following areas you have seen improvements among new CPAs, since the implementation of the 150-hour requirement? You may choose more than one.
O A. General Business
B. Financial Accounting
O C. Auditing
D. Regulation

Q4 In which of the following areas you would like to see improvements among new CPAs? You may choose more than one.
A. General Business
B. Financial Accounting
C. Auditing
D. Regulation

Q5 In your opinion, how many of the 30 additional credits should be allocated to each of the following areas? Total points should add up to 30 .

General Business

Financial Accounting

Auditing

Regulation

Q6 Which would be best strategy to obtain the 30 additional credits.

One additional year in college

O A master's degree in accounting

O Taking online credits while working

O Pick up a second major or minor

Q7 How many years have you worked as an accountant?

Q8 What year did you graduate from college?

Q9 What year of college are you in?
A. Freshman
B B. Sophomore
C. Junior
D. Senior
E E. Fifth Year College
F. First Year Master's
G. Second Year Master's

Q10 How many credit hours were (are) required when you applied (apply) for your CPA license?
O A. 120
B $\quad 150$

Q11 What is your gender?
A. Female
O Male
C. Gender identify not listed 
Q12 Please specify your ethnicity
O A. White
B B. Hispanic or Latino
C. Black or African American
D. Native American or American Indian
E. Asian / Pacific Islander
F. Other

Q13 What is the highest degree or level of school you have completed?
$\mathrm{O}$ A. Bachelor's Degree
B Master's Degree
C. Professional Degree
D. Doctorate Degree
E. Bachelor's Degree in progress

Q14 What is the number of employees in your organization?
A. $1-10$
O B. $11-50$
C. $51-100$
O D. $101-500$
O E. $501-5,000$
F. Over 5,000 